\title{
DENSIFIED RADIATA PINE FOR STRUCTURAL COMPOSITES
}

\author{
Frederick A. Kamke ${ }^{1}$
}

\author{
In memoriam of Dr. Walter G. KAUMAN
}

\begin{abstract}
A novel wood-based composite has been developed for use in structural applications. The process was designed to utilize rapidly-grown, low density, wood species. Plantation grown radiata pine is particularly well suited to this process. This is a laminated composite, where the lamina may be comprised of various materials, some of which have been treated with the viscoelastic thermal compression (VTC) process. The VTC process increases the density of wood, without causing fractures in the cell wall, thus increasing strength and stiffness of the wood material. The process may be applied to veneer, sawn wood, or strand composites. The VTC lamina is then bonded to other lamina to produce the final product. The strength and stiffness of this VTC composite exceeds any wood-based composite that is currently on the market. For example, modulus of elasticity in bending of over $20 \mathrm{GPa}$ is easily obtainable.
\end{abstract}

Keywords: Wood modification, densification, compression, composite, thermal treatment, viscoelastic.

\section{INTRODUCTION}

The wood products industry continues to increase its dependence on forest plantations as a source of raw material. There are now more than 124 million hectares of forest plantations throughout the world, of which $95 \%$ is classified as industrial use. Worldwide, Pinus species comprise $20 \%$ of the total plantation land area (FAO 2001). In South America plantation forest area has increased by more than $300 \%$ since 1980 (Carle et al. 2002). Historically, plantation management has been directed at producing wood for pulp or lumber. Rapidly grown softwood species are often characterized by wide grown rings and low density. Furthermore, if harvested at an age of less than 20 years, the wood will contain a high percentage of juvenile wood. Consequently, softwood species from short-rotation plantations typically produce wood with low strength and stiffness, which is undesirable for structural applications.

Radiata pine (Pinus radiata) is perhaps the most widely planted Pinus species in the Southern Hemisphere. Rapid growth and desirable lumber and pulp qualities have caused it to be introduced to commercial forestry in Australia, New Zealand, Argentina, Chile, Uruguay, Kenya, and the Republic of South Africa. Radiata pine is also a rapidly emerging plantation species in China. In many of these countries, radiata pine is a mainstay of the forest economy, both for internal markets and export, and reducing cutting pressure on native forests. In Chile there are 1.4 million hectares of radiata pine plantations, which represent approximately 75\% of Chile's forest plantation area (FAO 2001).

The reported density of radiata pine varies by geographic region throughout the world, but typically is in the range of 400 to $500 \mathrm{~kg} / \mathrm{m}^{3}$. There has been some success in Chile, through genetic selection, to increase growth rate of radiata pine without decreasing density (Zamudio et al. 2002), and there is conflicting evidence concerning the relationship between growth rate and density for the hard pines (Saranpää 2003). Radiata pine, like other softwoods, increases in density from pith to bark and there are large differences between earlywood and latewood density. The earlywood - latewood density ratio in radiata pine was reported to be 0.41 by Downes (2003). For example, for an average density of $450 \mathrm{~kg} /$ $\mathrm{m}^{3}$, the earlywood may have a density of only $300 \mathrm{~kg} / \mathrm{m}^{3}$ (assuming a growth ring is two-thirds earlywood).

\footnotetext{
${ }^{1}$ JELD-WEN Professor. Dept. Wood Science and Engineering. Oregon State University

Corvallis, Oregon, 97333 USA.

Corresponding author: fred.kamke@oregonstate.edu

Received: December, 01, 2005. Accepted: March 14, 2006
} 
Bending properties of wood are positively correlated with density. Radiata pine is generally lower in density than the other hard pines. It has an ultimate bending strength of approximately $75 \mathrm{MPa}$ and modulus of elasticity of approximately $9 \mathrm{GPa}$ (based on mean density of $480 \mathrm{~kg} / \mathrm{m}^{3}$ ). For application in the manufacture of such structural composites as laminated veneer lumber (LVL), ultimate bending strength in excess of $80 \mathrm{GPa}$ and modulus of elasticity greater than $15 \mathrm{GPa}$ is desirable. This report demonstrates the technical feasibility of modifying radiata pine wood to improve its strength and stiffness for use in the manufacture of structural composites.

\section{BACKGROUND}

It is well known that most mechanical properties of wood are correlated with density. Wantanabe et al (1999) clearly illustrated this relationship with measured Young's modulus in the tangential direction as a function of density for several softwood species (Figure 1). In summarizing the mechanical properties of 43 softwood species and 66 hardwood species, the USDA Wood Handbook (USDA 1999) suggests that mechanical properties within a species tend to vary linearly with density.

Wood with inadequate mechanical properties can be modified by various combinations of compressive, thermal and chemical treatments. Wood can be densified by impregnating its void volume with synthetic or natural polymers in their liquid form and then solidifying by chemical reaction or cooling of the impregnant. Alternatively, wood density can be increased by compression in the transverse direction (Kollmann et al.1975). The densification of solid wood and laminated wood has been a viable commercial process (Rowell and Konkol, 1987). Applications for chemically-treated densified wood have included patterns and dies, tooling, vehicle parts, sports equipment, gears, bearings, and many others. In the United States, patents on methods of densifying wood without chemical treatment date back to the early $20^{\text {th }}$ century (Sears, 1900; Walch and Watts, 1923; Olesheimer, 1929; Brossman, 1931). These patents did not adequately consider plasticization of the wood or stabilization of the final product; for this reason, the methods described therein have not been adopted by the industry (Kollmann et al. 1975).

Another densified wood product created in the United States is Compreg (Stamm and Seborg 1941). Compreg is resin-treated compressed wood. It is normally made by treating solid wood or veneer with water-soluble phenol formaldehyde resin and compressing it to the desired density and thickness. Compreg is much more dimensionally stable than non-impregnated compressed wood. However, treating resins harden within the cell wall making the treated wood brittle.

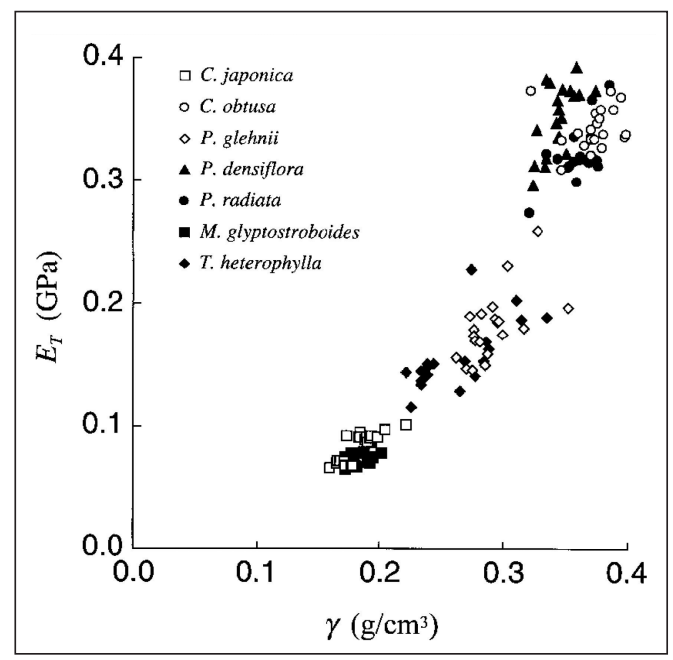

Figure 1. Relationship between tangential Young's modulus and density _for selected wood species (Wantanabe et al 1999). 
Unfortunately, untreated, compressed solid wood and veneer tend to undergo irreversible "springback" or recovery from compression when exposed to moisture. A second compressed wood product developed in the U.S. that is not treated with resin is Staypak (Seborg et al. 1962). Staypak is produced by compressing wood at a moisture content equal to or below that which it will have in service. One of the problems associated with making of Staypak is that the panels must be cooled to $100^{\circ} \mathrm{C}$ or less while under the full pressure. Due to the thermoplastic nature of the lignin, and because the moisture content of the wood is only slightly less after compression than prior to pressing, considerable springback will occur if the product is removed while still hot (Kollmann et al. 1975). This necessity and other disadvantages of Staypak prevented this product from being adopted by the industry.

There have been many studies relating to wood stabilization by various treatments. Hillis (1984) reviewed the literature about stabilization of wood by a heating process. The effect of steam pretreatment on wood was investigated by Hsu et al. (1988); Inoue et al. (1993); Inoue et al. (1996); and Kawai et al. (1992). Lately, the effect of heat on the dimensional stability of compressed wood has been evaluated by Dwianto et al. (1996). Tomme et al. (1998) and Navi and Girardet (2000) evaluated thermohygromechanical treatment in order to produce densified wood with stable deformation.

Dwianto et al. (1996) found that preheating had a great influence on permanent fixation. According to their results, the permanent fixation of compressive deformation in wood resulted from the release of stresses stored in microfibrils and the "matrix substance" (presumed by the authors to be lignin) of the cell wall due to their degradation. At the conditions evaluated the major thermal degradation products were likely derived from the hemicellulose content.

Hsu et al. (1988) developed a steam pretreatment process to produce highly dimensionally stable wood-based composites. They found that steam pretreatment causes partial hydrolysis of hemicelluloses for both hardwoods and softwoods, which greatly increases the compressibility of wood (i.e., reduces the tendency of internal stresses to build up in composites during hot pressing).

Inoue et al. (1993) found that almost complete fixation can be achieved by post-steaming compressed wood for $1 \mathrm{~min}$. at $200^{\circ} \mathrm{C}$ or $8 \mathrm{~min}$. at $180^{\circ} \mathrm{C}$. There was a large increase in hardness and only a slight decrease in bending modulus (MOE) and bending strength (MOR). Inoue et al. (1996) also investigated the effect of pre-steaming. They found that the degree of recovery decreases if the press time and temperature increase. Pre-steaming increases the compressibility of wood and reduces the amount of stored stress due to the viscous flow of wood substances.

Kawai et al. (1992) produced laminated veneer lumber (LVL) by steam-injection pressing. They found that MOR and MOE of compressed LVL increased with increasing density. The dimensional stability of LVL has been improved considerably. They also have proposed the mechanism responsible for the fixation of compression set by steam treatment. They hypothesize that relaxation of the stresses stored in the microfibrils and fixation of the compressive set is due to: rapid hydrolysis of hemicellulose and partial degradation of lignin; partial hydrolysis of cellulose in amorphous and paracrystalline regions, and reorientation in the crystalline region by steam treatment.

Another process to enhance the strength and stiffness of low-density wood species using steam, heat and mechanical compression has been termed Viscoelastic Thermal Compression, (VTC) (Kultikova, 1999; Kamke et al., 2000). However, previous descriptions of this process have been limited to batch processes which utilize constant environmental conditions to produce flat, densified materials. Thus, previous VTC procedures are not suitable for the industrial manufacture of densified wood products. In addition, previous VTC methodology dealt only with whole wood and did not address the manufacture of laminae from veneer or composite panels for use in structural laminated composites. 
This report summarizes an example of a prototype structural composite produced from radiata pine VTC wood, and hopefully, demonstrates the potential for commercial production. Although the VTC process has been evaluated for several species, this report has a focus on radiata pine.

\section{MATERIALS AND METHODS}

\section{VTC Process}

Solid-sawn pieces and rotary-peeled veneer of radiata pine (Pinus radiata) were obtained from New Zealand. The wood came from trees that were less than 20 years old. Only the sapwood was used. Due to phytosanitation requirements, all of the wood was subjected to a thermal treatment at $70^{\circ} \mathrm{C}$ for 3 hours prior to shipment. Once received the samples were stored in the laboratory for several months and then placed in a controlled environment room at $20^{\circ} \mathrm{C}$ and $65 \%$ relative humidity until equilibrium was reached at a moisture content of approximately $12 \%$.

The laboratory VTC apparatus may accommodate specimens up to $25 \mathrm{~mm}$ by $75 \mathrm{~mm}$ by $175 \mathrm{~mm}$, or up to five specimens may be pressed simultaneously with a combined thickness of $25 \mathrm{~mm}$. The design of the apparatus was described previously (Kamke et al 2000), although some recent modifications have been made. Figure 2 is a photograph of the 50 liter sealed vessel, which contains the press. The temperature of the environment inside the vessel is controlled by an electric heating jacket. The steam injected into the vessel is supplied by an independently controlled boiler, which assists with temperature control. Saturated steam pressure up to $200^{\circ} \mathrm{C}$ is obtainable. Gas pressure is controlled with a solenoid valve in series with a needle valve and a pressure transducer. The platens (Figure 3) have independent temperature control using electrical resistance heating. The hydraulic cylinder is mounted outside of the vessel, as shown in Figure 2. The hydraulic cylinder is attached through a flange to the ram, which is inside the vessel. The movement of the ram is accomplished by a collapsible, stainless-steel bellows. The heated platens are machined with a channel that defines the target thickness of the wood. Thus the platen performs that task of mechanical stops.

The VTC apparatus is preheated to the target temperature prior to insertion of the specimen. Once the lid is clamped to the vessel, the treatment schedule is initiated. The key to the VTC process is to impart a rapid moisture loss from the wood specimen immediately prior to compression. This causes the well known mechano-sorption affect, which is manifested in an extremely low compression modulus. Densification is thus performed without causing failures to the wood cell wall.

The radiata pine veneer, nominal $3 \mathrm{~mm}$ thick, with a moisture content of $12 \%$ and a dry-basis density of $0.41 \mathrm{~g} / \mathrm{cm}^{3}$, was treated with the VTC process. The initial condition inside the vessel was set at $175^{\circ} \mathrm{C}$ and $862 \mathrm{kPa}$ steam pressure. At this pressurized condition the wood quickly adsorbed moisture to approximately $20 \%$ over a period of $3 \mathrm{~min}$. Compression pressure was ramped up to $3600 \mathrm{kPa}$ and held for $180 \mathrm{~s}$. Rapid decompression to $100 \mathrm{kPa}$ followed, which coincided with the release of the compaction pressure. The wood rapidly lost moisture over a 10 second interval, and was continuing to loose moisture, when the compaction pressure was again applied, to a level as needed, until a thickness of approximately $1.6 \mathrm{~mm}$ was achieved. The compression was held for $3 \mathrm{~min}$. at $175^{\circ} \mathrm{C}$, followed with an annealing phase at $200^{\circ} \mathrm{C}$ for $5 \mathrm{~min}$. Without releasing the compaction pressure, a cooling phase followed, until the temperature of the specimen dropped below $100^{\circ} \mathrm{C}$. Compaction pressure was then released.

The compression of the 3-mm veneer was performed with mechanical stops in the press. These stops controlled the target thickness to $1.6 \mathrm{~mm}$. The applied compaction pressure (3600 $\mathrm{kPa})$ was more than adequate to reach a thickness of $1.6 \mathrm{~mm}$. It is unclear how much compression force was required to reach the target thickness, since the mechanical stops contributed significantly to the resistance once the target thickness was obtained. 

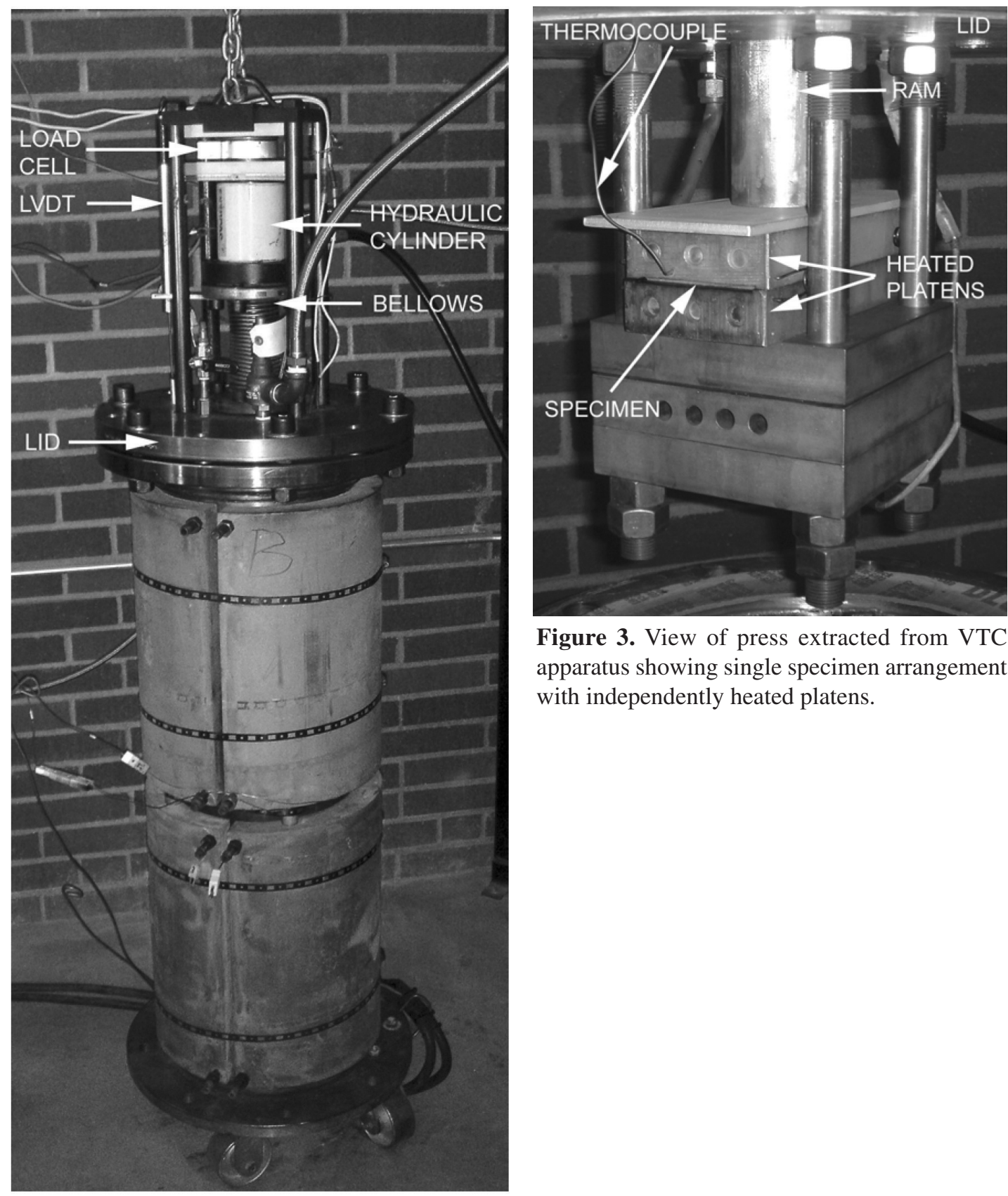

Figure 3. View of press extracted from VTC apparatus showing single specimen arrangement with independently heated platens.

Figure 2. VTC apparatus that was used to compress the wood specimens.

The 4-mm and 8-mm solid-sawn wood specimens received the same VTC treatment as the veneer.

The 4-mm specimens easily reached the $1.6 \mathrm{~mm}$ target thickness with a maximum compression of $3600 \mathrm{kPa}$. The 8-mm specimens were compressed in the second stage to a fixed compression pressure, $3600 \mathrm{kPa}$. The stops were never reached. Depending on the initial density of the specimen, the compressed thickness varied. The higher density specimens were compressed to a lesser extent. This yielded VTC specimens with a final density that was approximately equal. Some thickness recovery was observed for all specimens. 
After VTC processing the specimens were weighed and dimensions measured (Table 1). All specimens were then placed in an environment controlled room set at $20^{\circ} \mathrm{C}$ and $65 \%$ relative humidity. Specimen dimensions were again measured after moisture content conditioning.

Table 1. VTC and control specimen properties before and after processing. Coefficient of variation $(\mathrm{COV}, \%)$ is given in parentheses. Thickness and dry-basis density were based on specimen dimensions at the moisture content at time of testing.

\begin{tabular}{|l|c|c|c|c|c|}
\hline $\begin{array}{l}\text { Specimen / } \\
\text { Thininal Initial } \\
\text { Thickness }\end{array}$ & $\begin{array}{c}\text { Number of } \\
\text { Specimens }\end{array}$ & $\begin{array}{c}\text { Average } \\
\text { Initial } \\
\text { Thickness } \\
{[\mathrm{mm}]}\end{array}$ & $\begin{array}{c}\text { Average } \\
\text { Final } \\
\text { Thickness } \\
{[\mathrm{mm}]}\end{array}$ & $\begin{array}{c}\text { Average } \\
\text { Initial } \\
\text { Density } \\
{\left[\mathrm{g} / \mathrm{cm}^{3}\right]}\end{array}$ & $\begin{array}{c}\text { Average } \\
\text { Final } \\
\text { Density } \\
{\left[\mathrm{g} / \mathrm{cm}^{3}\right]}\end{array}$ \\
\hline 3-mm & 10 & 3.14 & 1.67 & 0.412 & 0.735 \\
veneer & $(3.19)$ & $(6.00)$ & $(7.84)$ & $(8.29)$ \\
\hline 4-mm & 20 & 4.30 & 1.59 & 0.390 & 1.01 \\
sawn wood & & $(0.80)$ & $(2.52)$ & $(3.92)$ & $(6.55)$ \\
\hline 8-mm & 20 & 7.92 & 2.83 & 0.385 & 1.04 \\
sawn wood & & $(2.17)$ & $(8.12)$ & $(5.08)$ & $(5.45)$ \\
\hline
\end{tabular}

\section{VTC Composite Manufacture}

The VTC wood specimens were used to produce 3-layer, laminated composites. The VTC wood laminas were placed in the two outer layers, and a piece of untreated wood, of the original thickness, was placed in the core layer. The specimens were bonded with a liquid phenol formaldehyde resin, which was a commercial plywood formulation obtained from Hexion Specialty Chemicals of Springfield, Oregon. The adhesive was spread by a roller at $125 \mathrm{~g} / \mathrm{m}^{2}$. Bonding was done in a heated press at $150^{\circ} \mathrm{C}$ and $700 \mathrm{kPa}$ for $4 \mathrm{~min}$. After hot-pressing, the specimens were returned to the environment room $\left(20^{\circ} \mathrm{C}\right.$, $65 \%$ relative humidity).

\section{Testing}

Static bending tests were performed on all of the untreated and VTC wood components. Prior to VTC processing, the specimens were only tested within their elastic range to obtain MOE. VTC processing was then performed and the compressed specimens were again tested for MOE within the elastic range. These specimens were then used to produce the 3-layer laminated composites. The 3-layer VTC composites were tested in bending to failure. All of the specimens were tested before compression, after compression, and after manufacture into a 3-layer composite. For all of the specimens, the test span was $150 \mathrm{~mm}$, the load was applied at the midpoint in 3-point bending, and the loading rate was $3 \mathrm{~mm} / \mathrm{min}$.

\section{RESULTS AND DISCUSSION}

Bending test results for the uncompressed specimens and the VTC laminas are shown in Table 2. The 3-mm radiata pine veneer increased in MOE by $116 \%$ in comparison to the untreated wood. The 4$\mathrm{mm}$ and $8-\mathrm{mm}$ solid-sawn wood increased in MOE by $174 \%$ and $152 \%$ respectively. The corresponding density change was $78 \%$ for the 3-mm veneer, with $159 \%$ and $170 \%$ respectively for the $4-\mathrm{mm}$ and 8 $\mathrm{mm}$ solid-sawn wood. The change in MOE was consistent with the change of density. The 3-mm veneer was subjected to the least amount of densification, which resulted in the smallest increase in MOE. The 8-mm solid-sawn specimens had the lowest initial MOE. These specimens had an initial density that was the same as the 4-mm specimens. However, the $8-\mathrm{mm}$ specimens generally contained wood that originated closer to the pith and may have contained a greater percentage of juvenile wood. 
Table 2. Bending test results for the uncompressed (initial) and VTC (final) specimens.

\begin{tabular}{|l|c|c|c|c|}
\hline $\begin{array}{l}\text { Specimen / } \\
\text { Nominal Initial } \\
\text { Thickness }\end{array}$ & $\begin{array}{c}\text { Initial MOE } \\
\text { GPa } \\
(C O V \%)\end{array}$ & $\begin{array}{c}\text { Final MOE } \\
\text { GPa } \\
(C O V \%)\end{array}$ & $\begin{array}{c}\text { Initial Specific } \\
\text { MOE } \\
\text { GPa }\end{array}$ & $\begin{array}{c}\text { Final Specific } \\
\text { MOE } \\
\text { GPa }\end{array}$ \\
\hline $\begin{array}{l}\text { 3-mm } \\
\text { veneer }\end{array}$ & $\begin{array}{c}\text { (18.37 } \\
\text { 4-mm }\end{array}$ & $\begin{array}{c}20.2 \\
(19.2)\end{array}$ & 22.7 & 27.5 \\
sawn wood & 7.74 & 21.2 & 19.8 & 21.0 \\
\hline $\begin{array}{l}\text { 8-mm } \\
\text { sawn wood }\end{array}$ & $(15.3)$ & $(16.0)$ & & 13.8 \\
\hline
\end{tabular}

Table 2 also lists the specific MOE values before and after VTC treatment. This value is obtained by dividing the MOE by the relative density (relative density = dry-basis density / density of water). If MOE is proportional to density, and there are no changes in the cell wall due to micro fractures or chemical modifications, the specific MOE value should not change as a result of the VTC treatment. Only the $3-\mathrm{mm}$ veneer specimens indicated a statistically significant difference $(\mathrm{a}=0.05)$. In this case the VTC wood had a greater specific MOE than the untreated wood. It is possible that both micro fractures and chemical modification take place. Microscopic observations (300 x) did not reveal any obvious micro fractures in the cell wall or between cells of the VTC wood. Thermal degradation occurs, as evidenced by the darkening of the wood. This would tend to degrade the stiffness. However, if some of the degradation products are able to form chemical bonds with the cell wall polymers, stiffness of the cell wall may increase. It is suggested that both phenomena occur. Perhaps the formation of cross-links within the cell wall served to repair the micro fractures (lathe checks) in the 3-mm veneer that were present before VTC treatment, and that this explains the significant increase of the specific MOE after VTC treatment.

Bending test results for the 3-layer laminated composites are shown in Table 3. In comparison to the uncompressed specimens (initial values in Table 2), the increase in MOE was 81\%, 130\%, and 190\% for the 3-mm veneer, 4-mm and 8-mm solid-sawn wood, respectively. Bending specimen failure was primarily due to a tensile failure in the bottom face layer, although a few compression failures in the top layer were observed. The dry-basis density of the 3-layer composites was $0.58,0.65$, and 0.66 for the 3-mm veneer, and 4-mm and 8-mm solid-sawn specimens respectively. Consequently, the increase in $\mathrm{MOE}$ for this simple 3-layer composite was 2 to 3 times the corresponding increase of density.

Table 3. Bending test results for the 3-layer laminated VTC composites.

\begin{tabular}{|l|c|c|}
\hline $\begin{array}{l}\text { Specimen / } \\
\text { Nominal Initial } \\
\text { Thickness }\end{array}$ & $\begin{array}{c}\text { MOE } \\
\text { GPa } \\
(C O V \%)\end{array}$ & $\begin{array}{c}\text { MOR } \\
\text { MPa } \\
(C O V \%)\end{array}$ \\
\hline $3 \mathrm{~mm}$ & 17.0 & 153 \\
veneer & $(6.2)$ & $(29.8)$ \\
\hline $4 \mathrm{~mm}$ & 17.8 & 173 \\
sawn wood & $(26.0)$ & $(19.5)$ \\
\hline $8 \mathrm{~mm}$ & 16.6 & 155 \\
sawn wood & $(19.1)$ & $(21.7)$ \\
\hline
\end{tabular}

No problems in the adhesive bonding were observed. Since the VTC process is accomplished in a pressurized system, there is little potential for the migration of extractive chemicals to the surface of the specimen, a situation that has been proposed as a major cause of surface inactivation, leading to poor bonding (Sernek et al. 2004). Furthermore, the rapid lost of moisture between the first and second stage compression is less likely to promote the migration of extractives than a slow drying process. Previous experience with VTC wood produced from radiata pine, loblolly pine (Pinus taeda), and yellow-poplar 
(Lireodendron tulipifera) confirmed that it is easily bonded with common commercial adhesive formulations (Kamke, 2004). Therefore, the surface quality of VTC wood is suitable for conventional bonding techniques and adhesives.

Dimensional stabilization in the presence of water is still an issue with VTC wood. Almost complete stabilization can be achieved using procedures described in the literature without chemical treatment (Inoue et al. 1993). Chemical treatments have also been proven to be effective to stabilize densified wood. Ongoing research is investigating dimensional stabilization as part of the VTC process. Early results indicate that as little as 2 percent maximum swelling may be achieved using just heat and steam to treat the wood.

The density of the cell wall substance in wood is generally agreed to be approximately $1.5 \mathrm{~g} / \mathrm{cm}^{3}$. If one assumes that the cell wall density can not be increased as a result of mechanical compression, $1.5 \mathrm{~g} /$ $\mathrm{cm}^{3}$ would be the theoretical limit of densification after all of the lumen volume is removed. Indeed, Seborg et al. (1962) achieved a density of $1.3 \mathrm{~g} / \mathrm{cm}^{3}$. In the present study, the maximum theoretical increase in density would be approximately $275 \%$ for the radiata pine (initial density $\sim 0.4 \mathrm{~g} / \mathrm{cm}^{3}$ ). A $170 \%$ increase was demonstrated, which was limited by the compression pressure used. Other trials have achieved a density of $1.3 \mathrm{~g} / \mathrm{cm}^{3}$. However, the required compression pressure increased exponentially and the risk of cell wall fracture also increased.

\section{CONCLUSIONS}

Structural wood-based composites may be produced from low density radiata pine and still yield strength and stiffness properties that are as good, or better, than any structural wood-based product that is currently produced. The process, called viscoelastic thermal compression, is a variation of previous art concerning wood densification. The key is a judicious timing of the dynamic wood moisture content, temperature, and compression rate. Bonding of the VTC wood can be achieved without difficulty. The wood utilization efficiency is good because the VTC composite is only partially composed of VTC wood, with the remainder being the untreated low density wood. Applications are for structural components in buildings, transportation systems, and casework. The process has promise to be scaledup to a commercial process.

\section{REFERENCES}

Brossman, J.R. 1931. Laminated wood product. US Patent 1,834,895. (Dec. 1, 1931).

Carle, J.; Vuorinen, P.; Del Lungo, A. 2002. Status and trends in global forest plantation development. For. Prod. J. 52(7/8):12-23.

Dwianto, W. ; Inoue, M.; Tanaka, F.; Norimoto, M. 1996. The permanent fixation of compressive deformation in wood by heat treatment. In Proceedings from the Third Pacific Rim Bio-Based Composites Symposium, Kyoto, Japan. Pp.231-239.

Downes, G. 2003. Relating wood properties to product properties: applications of SilviScan. CSIRO Forestry and Forest Products, Australia. Special seminar presented at Sustainable Engineered Materials Institute, Virginia Polytechnic Institute, Blacksburg, Virginia, Oct. 2, 2003.

FAO. 2001. Global forest resources assessment. FAO Forestry Paper 140, Food and Agriculture Organization of the United Nations, Rome. 
Hillis, W.E. 1984. High temperature and chemical effects on wood stability. I. General considerations. Wood Science and Technology. 18 (4): 281-293.

Hsu, W.E.; Schwald, W.; Schwald, J.; Shields, J.A. 1988. Chemical and physical changes required for producing dimensionally stable wood-based composites. Part I: Steam pretreatment. Wood Science and Technology, 22: 281-289.

Inoue, M.; Sekino, N.; Morooka, T.; Norimoto, M. 1996. Dimensional stabilization of wood composites by steaming I. Fixation of compressed wood by pre-steaming. In: Proceedings from the Third Pacific Rim Bio-Based Composites Symposium, Kyoto, Japan. pp. 240-248.

Inoue, M.; Norimoto, M.; Tanahashi, M.; Rowell, R.M. 1993. Steam or heat fixation of compressed wood. Wood and Fiber Science, 25(3): 224-235.

Kamke, F.A. 2004. A novel structural composite from low density wood. In: Proc. $7^{\text {th }}$ Pacific-Rim Bio-Composites Symp. Nanjing, China, Oct. 31 - Nov. 2, 2004, Vol. 2, p. 176-185.

Kamke, F.A.; Kultikova, E.V.; Lenth, C.A. 2000. Viscoelastic thermal compression of wood. In: Proc. $5^{\text {th }}$ Pacific Rim Bio-Based Composites Symp., December 10-13, 2000, Canberra, Australia. Ed. P. Evans, Dept. Forestry, Australian National University, Canberra, Australia, p. 292-302.

Kawai, S.; Wang, Q.; Sasaki, H.; Tanahashi, M. 1992. Production of compressed laminated veneer lumber by steam pressing. In Proceedings of the Pacific Rim Bio-Based Composites Symposium, p. 121-128.

Kollmann, F. P.; Kuenzi, E.W.; Stamm, A.J. 1975. Principles of wood science and technology. Vol. II Wood based materials. Springer-Verlag New York Heidelberg Berlin. pp. 139-149.

Kultikova, E. 1999. Material property evaluation of densified wood. M.S. Thesis. Virginia Polytechnic Institute and State University, Blacksburg, Virginia.

Navi, P.; Girardet, F. 2000. Effect of THM treatment on the structure and properties of wood. Holzforschung 54:287-293.

Olesheimer, L.J. 1929. Compressed laminated wood product and process of making the same. US Patent 1,707,135 (March 26, 1929).

Rowell, R.M.; Konkol, P. 1987. Treatments that enhance physical properties of wood. FPL, General Technical Report FPL-GTR-55, 12 pp.

Saranpää, P. 2003. Wood density and growth. In: Wood Quality and its Biological Basis. J.R. Barnett and G. Jeronimidis, Eds., Blackwell Pub., Oxford, p.87-117.

Sears, C.U. 1900. Process of preparing wood matrices. US Patent 646,547 (April 3, 1900).

Seborg, R.M.; Millett, M.A.; Stamm, A.J. 1962. Heat-stabilized compressed wood (Staypak). FPL, Report No. 1580 (revised), 22 pp.

Sernek, M.; Kamke, F.A.; Glasser, W.G. 2004. Comparative analysis of inactivated wood surfaces. Holzforschung 58:22-31. 
Stamm, A.J.; Seborg, R. M. 1941. Resin treated, laminated, compressed wood. Trans. Am. Inst. Chem. Eng., 37:385-397.

Tomme, F.; Girardet, F.; Gfeller, B.; Navi, P. 1998. Densified wood: an innovative product with highly enhanced characters. World Conference on Timber Engineering, Switzerland. Vol. 2, Pp. 640647.

USDA. 1999. Wood Handbook - Wood as an Engineering Material. For. Prod. Lab. Gen. Tech. Rep. FPL-GTR-113. U.S. Dept. Agri., For. Prod. Lab., Madison, Wis., p. 4-27.

Walch, F.J.; Watts, R.L. 1923. Composite lumber. US Patent 1,465,383 (Aug. 21, 1923).

Wantanabe, U.; Norimoto, M.; Ohgama, T. ; Fujita, M. 1999. Tangential Young's modulus of coniferous earlywood investigated using cell models. Holzforschung, 53:209-214.

Zamudio, F.; Baettyg, R.; Vergara, A.; Guerra, F.; Rozenberg, P. 2002. Genetic trends in wood density and radial growth with cambial age in radiate pine progeny test. Ann. For. Sci. 59:541-549. 